\title{
Upaya Tanggap Bencana Nasional Melalui Edukasi dan Pencegahan Penyebaran Covid-19 Di Kota Baubau
}

\author{
Jamaluddin $^{1}$, Sufiah Asri Mulyawati ${ }^{1 *}$, Zida Maulina Aini ${ }^{1}$, Sulastrianah ${ }^{1}$, Raja Al Fath \\ Widyaiswara $^{1}$
}

\author{
${ }^{1}$ Program Studi Kedokteran Fakultas Kedokteran Universitas Halu Oleo \\ *Email Korespondensi: phia_asri@yahoo.co.id \\ Telp: +6285326333447
}

\begin{abstract}
ABSTRAK
Kota Bau - Bau terletak pada selat Buton yang mempunyai aktivitas kelautan yang sangat tinggi, berperan sebagai titik transit sekaligus daerah penghubung bagi jalur nasional sekunder. Coronavirus adalah zoonosis atau virus yang ditularkan antara hewan dan manusia. Penyebaran penyakit ini telah memberikan dampak luas secara sosial dan ekonomi. Kegiatan ini bertujuan untuk mengembangkan pengetahuan dan pemahaman mengenai pencegahan dan penanganan covid-19. Metode pelaksanaan kegiatan meliputi kegiatan daring maupun luring seperti edukasi kepada masyarakat melalui video penyuluhan, pembagian masker, Hand sanitizer, dan pembagian Alat pelindung Diri. Kegiatan yang dilakukan dalam pengabdian ini melibatkan seluruh elemen masyarakat secara bersama-sama, bersinergi, multidisiplin, dan bermitra sehingga dapat membantu mengendalikan penyebaran Covid 19 dan menurunkan jumlah kasus diwilayah Kota Bau Bau. Program kerja yang dilaksanakan berdasarkan potensi dan permasalahan yang ada di Kota Bau Bau. Hasil dari pengabdian masyarakat ini berupa edukasi penanganan dan pencegahan Covid 19 dan penerapan protokol kesehatan di era new normal, pendistribusian masker kain, pendistribusian hand sanitizer, pembuatan sarana cuci tangan, serta pembagian alat pelindung diri bagi tenaga medis di kota Bau Bau. Capaian dan luaran kegiatan pengabdian kepada masyarakat meliputi peningkatan pengetahuan dan kesadaran masyarakat tentang pencegahan Covid 19 dan penerapan protokol kesehatan, peningkatan penerapan Pola Hidup Bersih dan Sehat, tersedianya Alat Pelindung Diri bagi tenaga kesehatan khususnya pada puskesmas dan rumah sakit.
\end{abstract}

Kata Kunci : Covid 19; edukasi; pencegahan

\begin{abstract}
The town of Bau - Bau is located in the Buton Strait, which has a very high maritime activity, acting both as a transit point and connecting area for secondary national routes. Coronaviruses are zoonoses or viruses that are transmitted between animals and humans. The spread of this disease has had wideranging social and economic consequences. This activity aims to develop knowledge and understanding of the prevention and treatment of Covid-19. The method of conducting activities includes online and offline activities such as educating the public through video counseling, distribution of masks, hand sanitizers and distribution of personal protective equipment. The activities carried out in this service involve all elements of society together, in synergy, multidisciplinary and in partnership to help control the spread of Covid 19 and reduce the number of cases in the Bau Bau City area. The work program was carried out based on the potential and the problems that exist in Bau Bau City. The results of this community service are in the form of education about the handling and prevention of Covid 19 and the application of health protocols in the new normal era, the distribution of cloth masks, the distribution of hand disinfectants, the making of hand washing facilities and the distribution of personal protective equipment for medical personnel in the city of Bau Bau. The achievements and outcomes of community service include increasing public knowledge and awareness about Covid 19 prevention and the
\end{abstract}


application of health protocols, increasing the adoption of a clean and healthy lifestyle, the availability of personal protective equipment for health professionals, especially in health centers and hospitals.

Keywords: Covid 19; education; prevention

\section{PENDAHULUAN}

Coronavirus adalah zoonosis atau virus yang ditularkan antara hewan dan manusia. Penyebaran penyakit ini telah memberikan dampak luas secara sosial dan ekonomi. Coronavirus-19 (COVID) telah dinyatakan sebagai pandemi dunia oleh WHO. Penyakit Korona 2019 atau yang lebih sering kita dengar sebagai COVID 19, merupakan penyakit pada daerah pernafasan disebabkan oleh salah satu jenis virus Korona ${ }^{1}$. Hingga saat ini, jumlah kasus penyakit ini mencapai angka 1.990 .745 jiwa yang tersebar di 166 negara, termasuk Indonesia ${ }^{2}$. COVID 19 pertama dilaporkan di Indonesia pada tanggal 2 Maret 2020 sejumlah dua kasus. Data 31 Maret 2020 menunjukkan kasus yang terkonfirmasi berjumlah 1.528 kasus dan 136 kasus kematian ${ }^{3}$.

Tingkat mortalitas COVID 19 di Indonesia sebesar 8,9\%, angka ini merupakan yang tertinggi di Asia Tenggara. Di Indonesia sendiri, per tanggal 14 April 2020, kasus yang terkonfirmasi positif sebagai pasien COVID 19 adalah sejumlah 4.839, dengan jumlah pasien sembuh sebanyak 426 orang dan pasien meninggal sebanyak 459 orang $^{4}$. Presiden Republik Indonesia telah menyatakan status penyakit ini menjadi Bencana Nasional Darurat pada tanggal 13 April 2020. Presiden juga telah mengeluarkan Keputusan Presiden No. 7 Tahun 2020 tentang Gugus Tugas Percepatan Penanganan Corona yang diketuai oleh Kepala Badan Nasional Penanggulangan Bencana (BNPB). Gugus Tugas ini bertujuan untuk meningkatkan ketahanan nasional di bidang kesehatan; mempercepat penanganan COVID 19 melalui sinergi antar kementerian/lembaga dan pemerintah daerah; meningkatkan antisipasi perkembangan eskalasi penyebaran COVID19; meningkatkan sinergi pengambilan kebijakan operasional; dan meningkatkan kesiapan dan kemampuan dalam mencegah, mendeteksi, dan merespons terhadap COVID 19. Menteri Pendidikan dan Kebudayaan juga telah mengeluarkan Surat Edaran No. 3 tahun 2020 mengenai Pencegahan Corona Virus Disease (COVID 19) pada satuan pendidikan ${ }^{5}$.

Pemerintah menghimbau masyarakat untuk melakukan langkah-langkah pencegahan seperti Pelaksanaan Hidup Bersih dan Sehat, sering mencuci tangan, menggunakan masker, dan melakukan physical distancing. Upaya pencegahan sudah secara massive dilakukan oleh 
pemerintah, namun jumlah pasien dan korban juga masih belum bisa ditekan secara signifikan. Masih banyak masyarakat yang belum secara sadar melaksanakan himbauan pemerintah. Selain itu, jumlah APD untuk tenaga kesehatan dan masyarakat juga dianggap masih belum memadai. Dalam upaya pencegahan dan pengendalian wabah COVID 19, kegiatan pengabdian kepada masyarakat yang dilakukan oleh Tim dosen dari Fakultas Kedokteran Universitas Halu Oleo, bersama mahasiswa dan pihak terkait, merupakan salah satu perwujudan nyata dari apa yang diarahkan oleh pemerintah saat ini.

Kota Bau Bau terletak pada selat Buton yang mempunyai aktivitas kelautan yang sangat tinggi dan dikelilingi oleh beberapa kecamatan dari beberapa kabupaten yakni kabupaten Buton, Kabupaten Buton Selatan, Kabupaten Buton Tengah. Dengan posisi tersebut, secara geostrategic kota Bau Bau berperan sebagai kota transit sekaligus daerah penghubung (conenecting area) antara kawasan Barat Indonesia (KBI) dengan kawasan Timur Indonesia (KTI) dimana kota Bau Bau berperan sebagai titik transit bagi jalur nasional sekunder yang menghubungkan ALKI III dan ALKI II ${ }^{6}$. Hal tersebut menjadikan para penumpang yang transit atau turun di Kota Bau Bau tentu akan berisiko untuk tertular dan menularkan penyakit tersebut. Para penumpang tersebut dikatakan ODP. Hal ini memerlukan perhatian khusus dari semua pihak untuk menanggulangi penyebaran Covid 19.

Data Gugus Tugas Penanganan VOVID-19 di Provinsi Sulawesi Tenggara (Sultra) mencatat bahwa seluruh wilayah di 17 kabupaten/kota di Sultra terdapat orang dalam pemantauan (ODP), dimana Kota Baubau terbanyak mencapai 484 orang dan terendah Kabupaten Konawe Kepulauan hanya 8 orang. Data tersebut sesuai dengan data resmi yang dikeluarkan Tim Gugus Tugas hingga Kamis (26/3/2020) pukul 16.00 Wita. Dimana jumlah ODP secara keseluruhan di provinsi tersebut mencapai 2.337 orang $^{7}$.

Pemerintah Kota Bau - Bau melalui Tim Gugus Tugas Percepatan Penanganan Virus Corona mengemukakan bahwa terdapat 2 orang positif terpapar COVID 19. Hal tersebut diketahui setelah mendapatkan hasil rapid test yang reaktif. Kedua pasien tersebut ditetapkan memiliki status COVID 19 yang berbeda. Status pertama terklarifikasi sebagai OTG, sedangkan status kedua terklarifikasi $\mathrm{ODP}^{8}$. Data dari dinas kesehatan Provinsi Sulawesi Tenggarai yang di unduh pada laman sultraprov.go.id mencatat 19 orang dalam pemantauan di Kota Bau - Bau sampai dengan tanggal 17 April 2020 (Tabel 1). Laporan kasus pertama kali didapatkan pada pasien dengan riwayat bepergian keluar daerah kota Bau - Bau. Orang-orang yang memiliki riwayat bepergian keluar daerah, khususnya daerah dengan kejadian COVID 19 
merupakan kelompok dengan faktor resiko yang besar untuk terkena virus ini ${ }^{9}$. Hasil lacak pasien yang terkonfirmasi positif melaporkan pada kasus yang berkembang bukan hanya pada orang dengan riwayat kunjungan ke wilayah kota Kendari tetapi juga dari warga lokal kota Kendari sehingga Kendari ditetapkan sebagai daerah dengan transmisi lokal oleh Pemerintah Republik Indonesia ${ }^{10}$.

\subsection{Tujuan}

Pengabdian masyarakat terintegrasi KKN Tematik memiliki tujuan untuk mengembangkan pengetahuan dan pemahaman mengenai pencegahan dan penanganan Covid 19.

\subsection{Permasalahan}

Permasalahan yang dihadapi oleh mitra adalah kurangnya pengetahuan sebagian masyarakat tentang upaya pencegahan wabah Covid 19, terbatasnya akses untuk memperoleh APD yang memadai, masih banyaknya masyarakat yang tidak menerapkan PHBS, penggunaan masker dan Physical distancing.

\section{METODE PELAKSANAAN}

\subsection{Solusi dan Target Luaran}

Kegiatan ini merupakan kegiatan pengabdian kepada masyarakat yang terintegrasi KKN tematik untuk membantu menyelesaikan permasalahan masyarakat di Kota Bau Bau terkait upaya pencegahan dan penanggulangan Covid 19. Kegiatan ini dapat membantu program pemerintah dalam mengendalikan kasus Covid 19 dan penerapan protokol kesehatan dengan meningkatkan kemandirian, kesehatan dan kesejahteraan masyarakat, serta memperkuat sinergisme perguruan tinggi dengan stakeholder terkait. Peningkatan penerapan Perilaku Hidup Bersih dan Sehat (PHBS), penggunaan masker, mencuci tangan, dan menjaga physical distancing.

\subsection{Lokasi Kegiatan Pelaksanaan}

Waktu Pelaksanaan tanggal 14 Juni sampai dengan 14 Juli 2020 di Kelurahan Katobengke Kecamatan Betoambari Kota Bau Bau Sulawesi Tenggara. 


\subsection{Metode Kegiatan}

Kegiatan Pengabdian kepada Masyarakat Terintegrasi KKN Tematik di Kota Bau Bau disusun berdasarkan potensi dan permasalahan yang ada dan dilaksanakan melalui serangkaian kegiatan sebagai bentuk solusi yang ditawarkan. Kegiatan yang dilakukan dalam pengabdian pada masyarakat ini melibatkan seluruh elemen masyarakat secara bersamasama, sinergi, multidisiplin, dan bermitra sehingga dapat membantu mengendalikan penyebaran Covid 19. Secara teknis pelaksanaan kegiatan dilakukan dengan tahapan; Persiapan, dilakukan dengan menginventarisasi permasalahan dan sosialisasi program kerja; Pelaksanaan, dilakukan dengan melibatkan khalayak sasaran yang stategis, meliputi Dinas Kesehatan, Badan Nasional Penanggulangan Bencana, Satgas Covid 19, akademisi dari perguruan tinggi, serta warga masyarakat luas; Evaluasi dan monitoring, dilakukan secara periodik dengan melibatkan tim pelaksana, Dinas Kesehatan, BNPB dan Satgas Covid serta stakeholder yang terkait.

\section{HASIL DAN PEMBAHASAN}

Pelaksanaan pengabdian kepada masyarakat terintegrasi KKN Tematik tahun 2020 berbeda dengan tahun sebelumnya karena terjadinya pandemi Covid 19 sehingga kegiatan lebih dominan pada kegiatan daring dari pada luring. Namun demikian, komunikasi dan koordinasi lintas sektoral tetap dilakukan dengan upaya maksimal. Permasalahan yang telah diidentifikasi berdasarkan data hasil observasi dan wawancara dengan satgas Covid 19 kota Bau Bau telah dikonfirmasikan dengan perangkat pemerintah serta dengan analisis potensi yang ada. Berkaitan dengan hal tersebut, disusun rancangan program kerja untuk memfokuskan kegiatan dalam upaya mengatasi berbagai permasalahan tersebut.

Secara umum pelaksanaan progam kerja dapat dideskripsikan sebagai berikut:

1. Edukasi penanganan dan pencegahan Covid 19

Teknik pelaksanaan kegiatan edukasi dilakukan secara daring maupun luring. Edukasi di luar jaringan dilakukan dengan menggunakan poster, brosur atau pamflet yang berisi informasi tentang pencegahan Covid 19 dan edukasi di dalam jaringan dilakukan dengan penayangan video.

2. Pemasangan Tempat Cuci Tangan Portable Sebagai Langkah Penanganan Covid 19 
Pemasangan tempat cuci tangan portable dilakukan di tempat ibadah dan kantor kelurahan. Pemasangan tersebut dibarengi dengan pemasangan poster cara cuci tangan yang baik dan benar dan pemberian sabun cuci tangan.

\section{Pendistribusian Hand sanitizer}

Pembuatan Hand sanitizer dilaksanakan oleh mahasiswa kedokteran di Laboratorium kedokteran universitas Halu Oleo, yang selanjutnya diberikan ke Tim KKN yang berada di kota Bau Bau. Pendistribusian Hand sanitizer diwakili oleh beberapa orang mahasiswa KKN ke Lurah Katobengke, yang diserahkan secara simbolis yang dihadiri oleh warga masyarakat. Hand sanitizer juga diberikan ke Satgas Covid 19.

4. Pengembangan UMKM dalam rangka pembuatan Masker Kain

Tim KKN bekerja sama dengan UMKM di kelurahan Katobengke dalam hal pembuatan masker kain guna peningkatan pendapatan warga masyarakat yang terdampak Covid 19.

5. Pembagian/Pendistribusian Masker kain kepada masyarakat

Masker kain yang diperoleh dari UMKM didistribusikan kepada warga masyarakat terutama masyarakat yang tetap beraktivitas diluar rumah saat kondisi pandemi.

6. Pemberian APD kepada Gugus Tugas Percepatan Penanganan Covid 19 dan Tenaga

Kesehatan Di RSUD dan Puskesmas Setempat

Untuk pendistribusian APD diberikan langsung kepada tenaga Kesehatan di Puskesmas daerah setempat serta penyerahan secara langsung kepada ketua BNPB sebagai perwakilan gugus tugas covid-19 dalam rangka memberikan bantuan logistic berupa Alat pelindung diri (APD).

7. Pembuatan Poster dan Video Edukasi Pencegahan Covid 19

Pembuatan poster dan video edukasi yang disebarke media sosial agar masyarakat dan keluarga dapat melihat langkah-langkah pencegahan Covid-19 di masa new normal. 


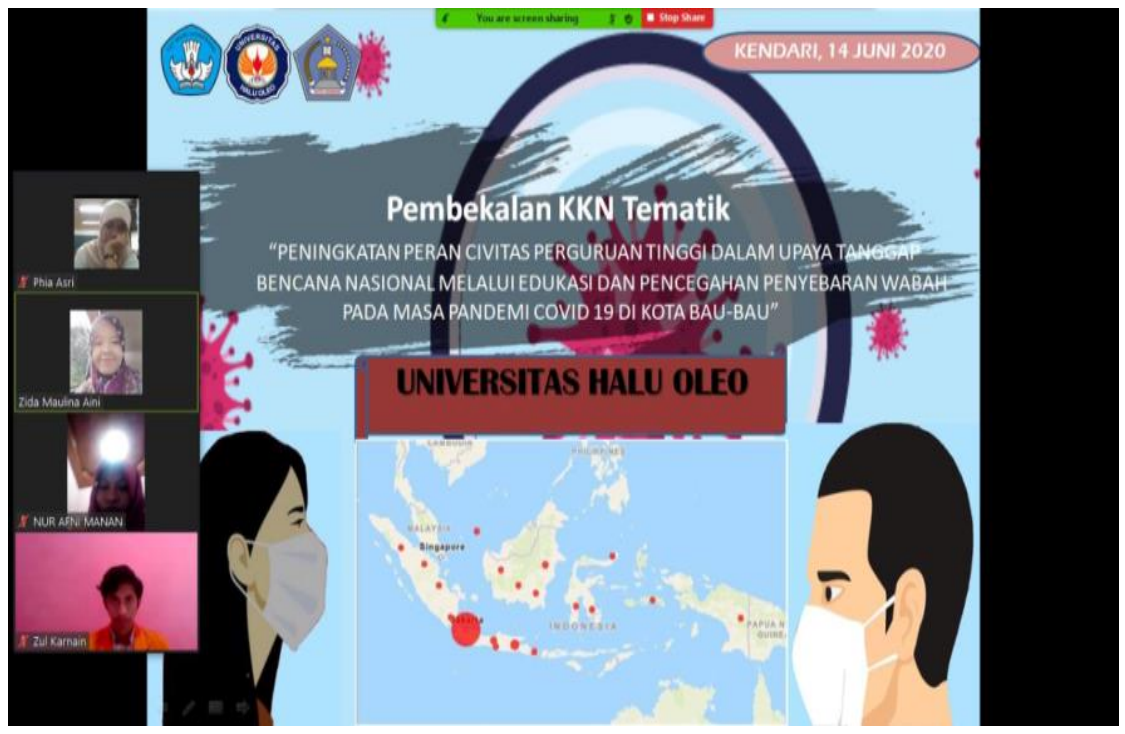

Gambar 1. Pembekalan KKN Tematik Kota Bau

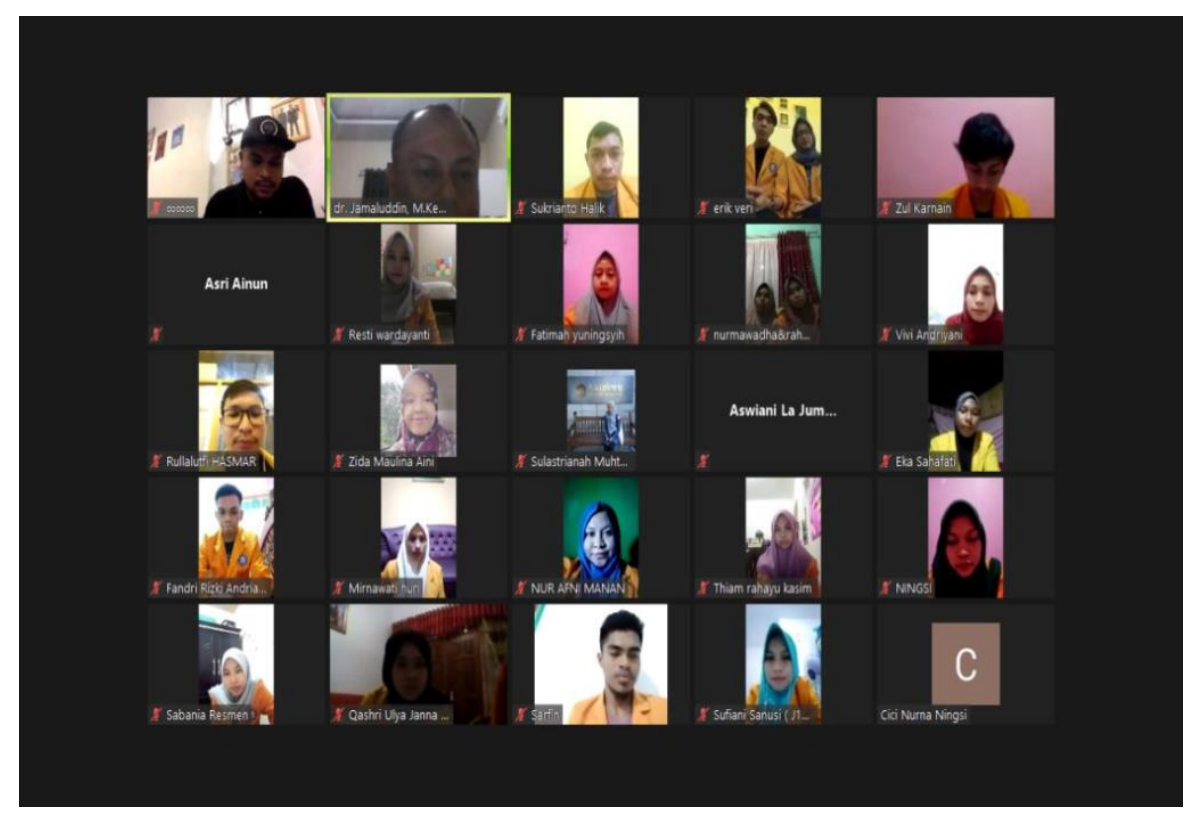

Gambar 2. Serah Terima Mahasiswa KKN Tematik dari DPL ke Lurah Katobengke 


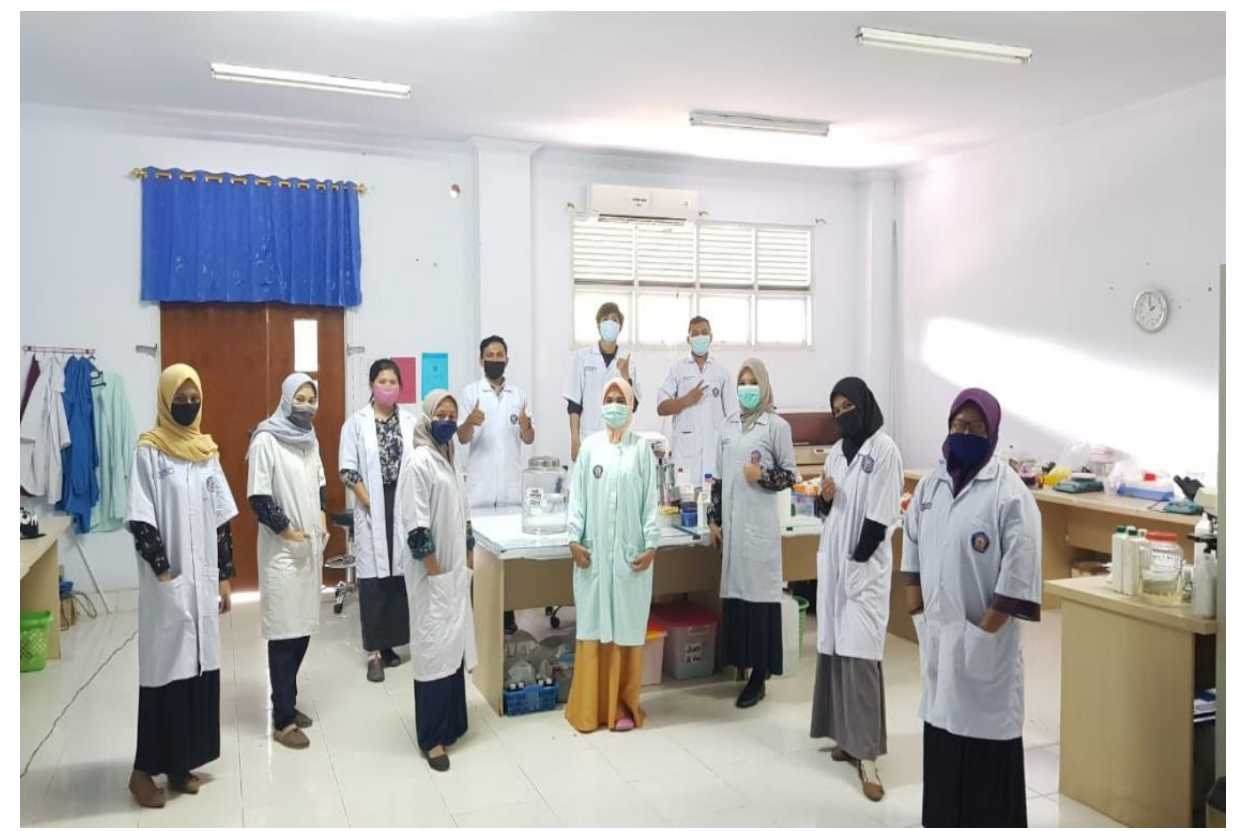

Gambar 3. Pembuatan Handsanitizer di laboratorium Fakultas Kedokteran Universitas Haluoleo

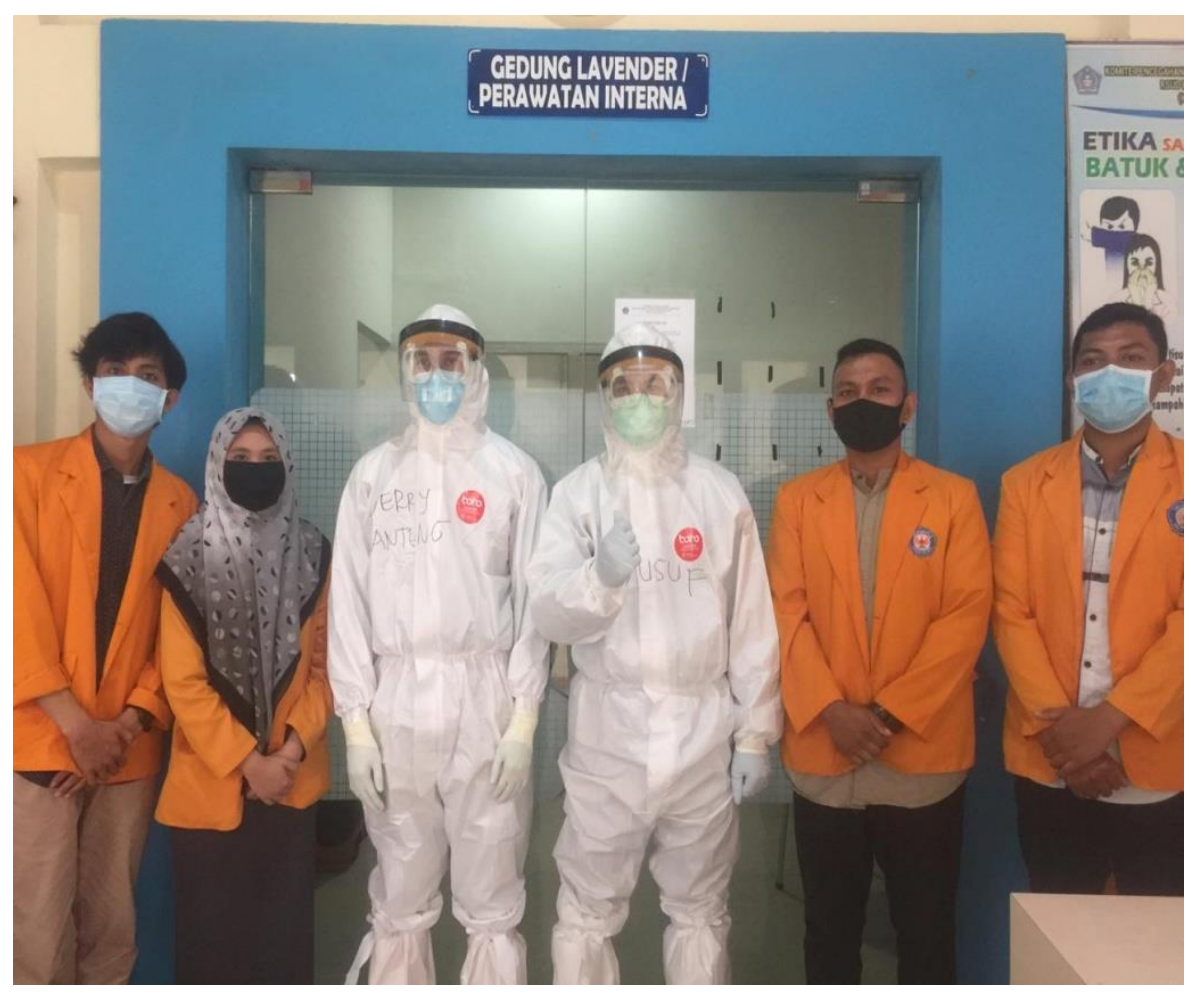

Gambar 4. Menemui dokter terkait pembuatan video Edukasi 


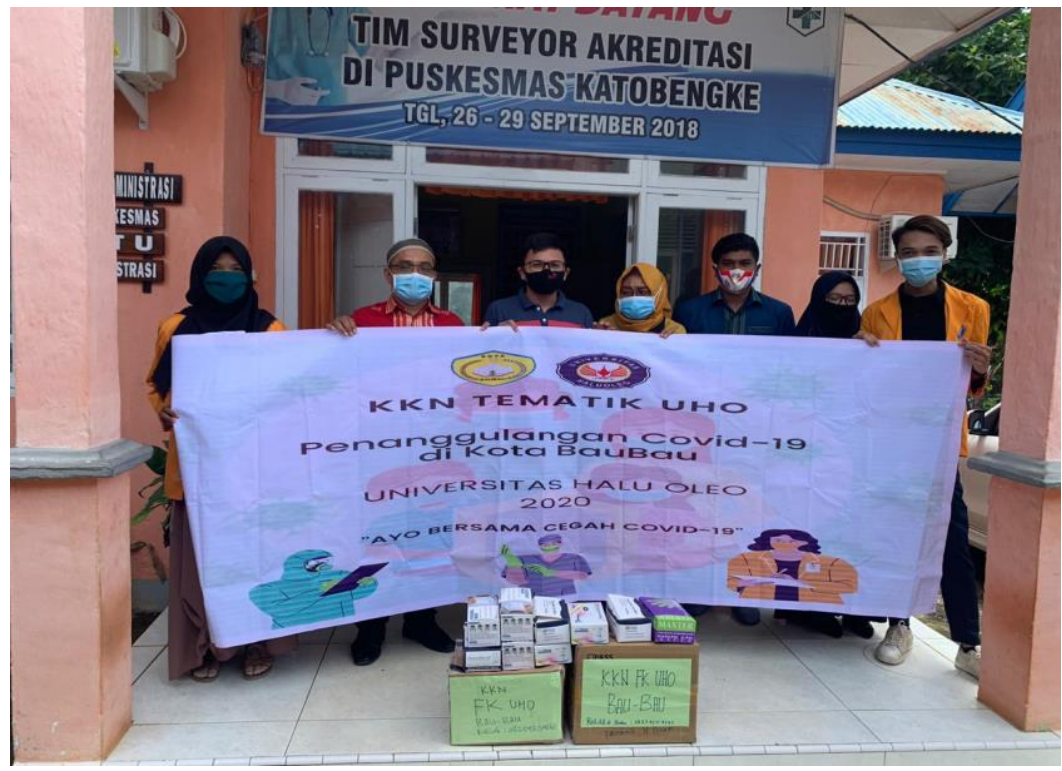

Gambar 5. Pembagian masker, face shield, sarung tangan, hand sanitizer ke puskesmas Katobengke

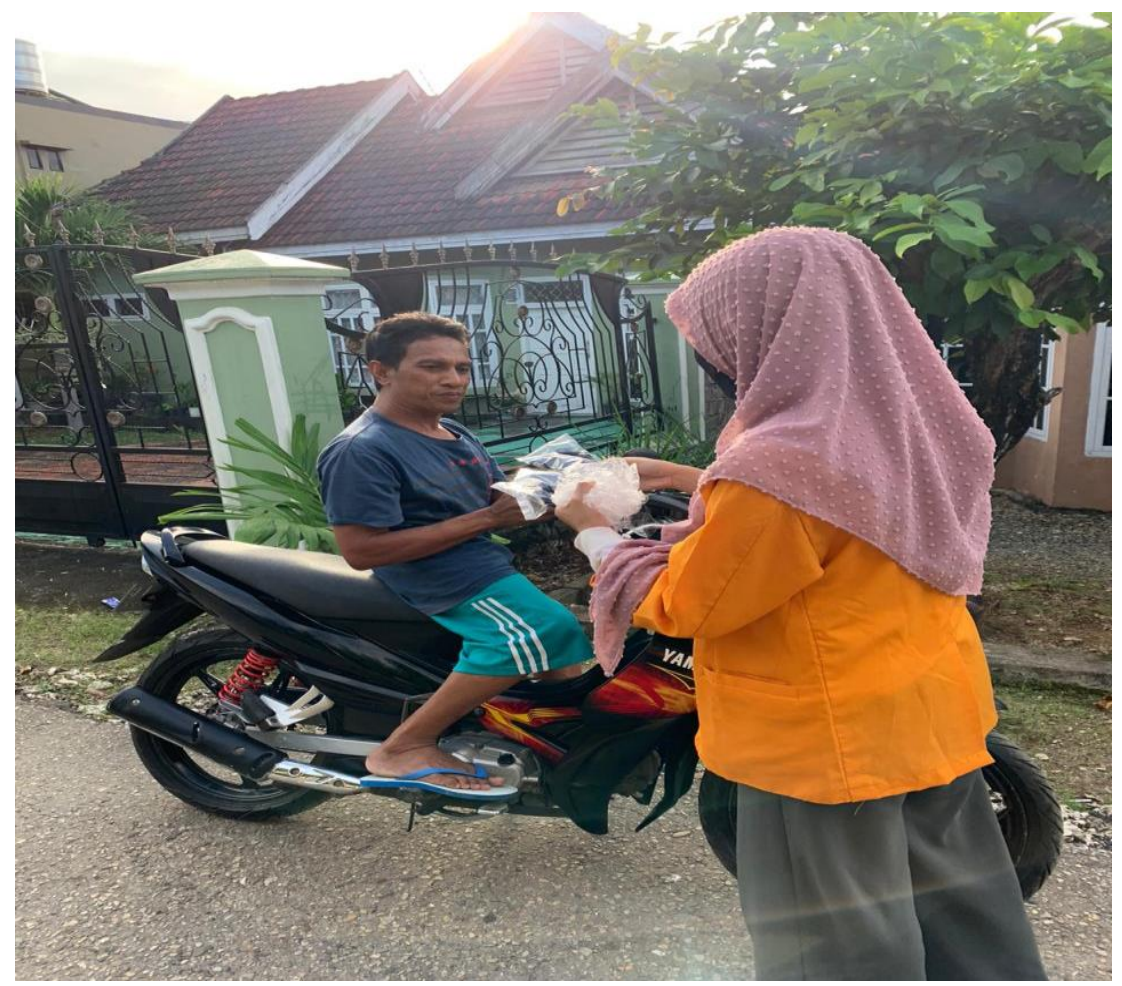

Gambar 6. Pembagian masker kepada warga masyarakat kelurahan Katobengke 


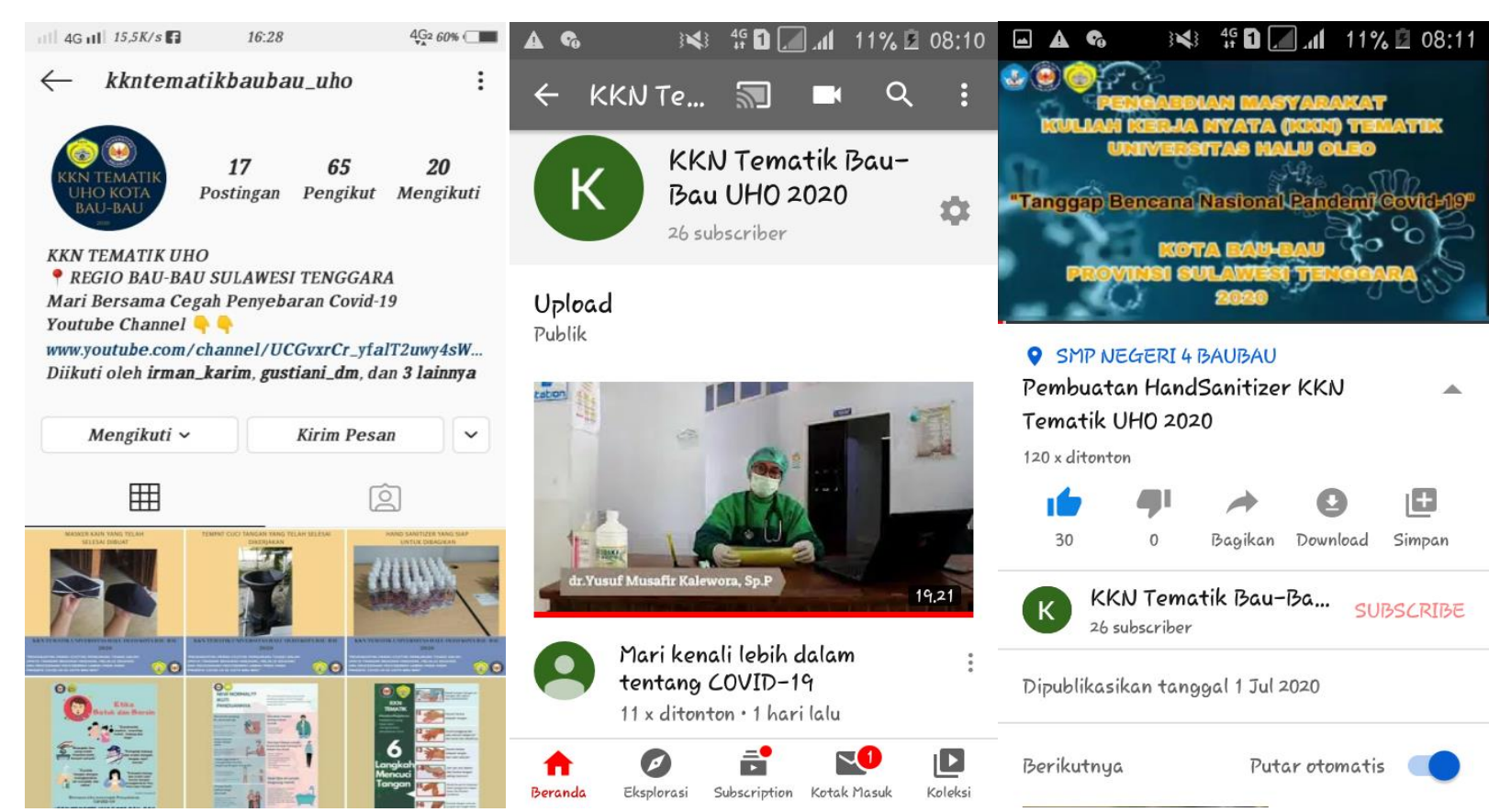

Gambar 7. Penyebaran poster dan video edukasi melalui media massa

Tabel 1. Data sebaran COVID 19 di Sulawesi Tenggara per Tanggal 17 April 2020

\begin{tabular}{|c|c|c|c|c|c|c|c|c|}
\hline \multirow[b]{2}{*}{ No } & \multirow[b]{2}{*}{ KABUPATEN } & \multirow[b]{2}{*}{$\begin{array}{l}\text { ORANG TANPA } \\
\text { GEJALA(OTG) }\end{array}$} & \multirow[b]{2}{*}{$\begin{array}{l}\text { ORANG DALAM } \\
\text { PEMANTAUAN (ODP) }\end{array}$} & \multirow[b]{2}{*}{$\begin{array}{l}\text { PASIENDALAM } \\
\text { PENGAWASAN (PDP) }\end{array}$} & \multicolumn{4}{|c|}{ POSITIF COVID-19 } \\
\hline & & & & & $\begin{array}{c}\text { JUMLAH KASUS } \\
\text { POSITIF }\end{array}$ & $\begin{array}{c}\text { SEMBUH } \\
\text { (PEMERIKSAAN } \\
\text { LAB HASIL 2X } \\
\text { NEGATIF) }\end{array}$ & MENINGGAL & $\begin{array}{l}\text { KASUS POSITIF MASIH } \\
\text { DALAM PEMANTAUAN } \\
\text { PENGAWASAN }\end{array}$ \\
\hline 1 & KABUPATEN KOLAKA & 0 & 31 & 0 & 1 & 0 & 0 & 1 \\
\hline 2 & KABUPATEN KONAWE & 0 & 5 & 1 & 3 & 0 & 0 & 3 \\
\hline 3 & KABUPATENMUNA & 4 & 40 & 4 & 0 & 0 & 0 & 0 \\
\hline 4 & KABUPATEN BUTON & 0 & 12 & 0 & 0 & 0 & 0 & 0 \\
\hline 5 & KOTAKENDARI & 89 & 29 & 3 & 21 & 4 & 1 & 16 \\
\hline 6 & KOTABAUBAU & 0 & 19 & 0 & 0 & 0 & 0 & 0 \\
\hline 7 & KABUPATEN KONAWESE_ATAN & 0 & 48 & 2 & 0 & 0 & 0 & 0 \\
\hline 8 & KABUPATEN KOLAKAUTTARA & 0 & 32 & 1 & 2 & 0 & 0 & 2 \\
\hline 9 & KABUPATEN WAKATOBI & 0 & 4 & 0 & 0 & 0 & 0 & 0 \\
\hline 10 & KABUPATEN BOMBANA & 2 & 13 & 1 & 0 & 0 & 0 & 0 \\
\hline 11 & KABUPATEN KONAWEUTARA & 0 & 4 & 0 & 0 & 0 & 0 & 0 \\
\hline 12 & KABUPATENBUTONUTARA & 0 & 12 & 0 & 0 & 0 & 0 & 0 \\
\hline 13 & KOLAKA TIMUR & 0 & 8 & 0 & 0 & 0 & 0 & 0 \\
\hline 14 & KONAWE KEPULAUAN & 0 & 18 & 0 & 0 & 0 & 0 & 0 \\
\hline 15 & MUNABARAT & 0 & 7 & 0 & 0 & 0 & 0 & 0 \\
\hline 16 & BUTONSELATAN & 0 & 10 & 0 & 0 & 0 & 0 & 0 \\
\hline 17 & BUTON TENGAH & 0 & 16 & 1 & 0 & 0 & 0 & 0 \\
\hline & TOTAL & 95 & 308 & 13 & 27 & 4 & 1 & 22 \\
\hline
\end{tabular}

SUMBER DATA : POSKO GUGUS TUGAS COVID19 PROVINSI SULAWESI TENGGARA 


\section{KESIMPULAN DAN SARAN}

Kesimpulan yang dapat diperoleh dari Pengabdian masyarakat yang terintegrasi Kuliah Kerja Nyata (KKN) tematik yang dilaksanakan di Kelurahan Katobengke Kecamatan Betoambari meliputi peningkatan pengetahuan dan kesadaran masyarakat tentang pencegahan penyebaran Covid 19 dan penerapan protokol kesehatan, peningkatan penerapan PHBS, tersedianya APD bagi tenaga kesehatan dan publiksi di media elektronik serta dihasilkannya video kegiatan.

\section{Ucapan Terima Kasih}

Ucapan terima kasih kami kepada Lembaga Penelitian dan Pengabdian Masyarakat (LPPM) Universitas Halu Oleo, Dekan Fakultas Kedokteran, Lurah Katobengke beserta jajarannya, serta seluruh mahasiswa KKN Tematik Kota Bau Bau serta beberapa pihak yang namanya kami tidak dapat sebutkan satu persatu. 


\section{DAFTAR PUSTAKA}

1. Cascella, et all; Michael Rajnik; Arturo Cuomo; Scott C. Dulebohn; Raffaela Di Napoli. 2020. Features, Evaluation and Treatment Coronavirus (COVID

19). NCBI https://infeksiemerging.kemkes.go.id/ diakses tanggal 15 April 2020, pukul 12:00 WITA

2. https://covid.19.go.id diakses tanggal 14 April 2020; Pukul 23.00 WITA

3. Susilo, A. et al. (2020) 'Coronavirus Disease 2019: Tinjauan Literatur Terkini Coronavirus Disease 2019: Review of Current Literatures', Jurnal Penyakit Dalam Indonesia, 7(1), pp. 45-67.

4. https://nasional.kompas.com/read/2020/04/14/16152541/update-kasus-COVID 19-diindonesia-ada-4839-bertambah-282-orang), diakses tanggal 15 April 2020.

5. https://www.kemdikbud.go.id/main/blog/2020/03/infografis-cegah-covid19-di-satuanpendidikan, diakses tanggal 15 April 2020.

6. Anonim, 2017, Rencana Pembangunan Jangka Menengah Daerah Kota Bau - Bau (RPJMD). Kota Bau - Bau.

7. https://sultra.antaranews.com/berita/330662/seluruh-wilayah-sultra-miliki-data-odpkasus-covid-19-kota-baubau-capai-484-orang diakses tanggal 18 April 2020.

8. https://kendaripos.co.id/2020/04/rapid-test-reaktif-dua-warga-baubau-positif-covid-19/ diakses tanggal 18 April 2020.

9. Kemkes RI, 2020. Penanganan COVID 19: Protokol Pintu Masuk Wilayah Indonesia (Bandara, Pelabuhan, PLBDN).

10. Kemkes RI. Pedoman Kesiapsiagaan Menghadapi Infeksi Novel Coronavirus (2019nCoV). Direktorat Jenderal Pencegahan dan Pengendalian Penyakit. Januari 2020. 